Counsellia: Jurnal Bimbingan dan Konseling 8 (1), 1 - 6 | Mei 2018

Copyright $@ 2017$ Universitas PGRI Madiun

ISSN: 2088-3072 (Print) / 2477-5886 (Online)

Available online at: http://e-journal.unipma.ac.id/index.php/JBK

DOI: 10.25273/counsellia.v8i1.2239

\title{
Perbedaan Minat Belajar Bimbingan dan Konseling Ditinjau dari Metode Pembelajaran Student Team Achievement Division
}

\author{
Titik Indrawati \\ Guru Bimbingan dan Konseling SMP Negeri 2 Kota Madiun \\ titikindrawati61@yahoo.co.id
}

\begin{abstract}
Abstrak
Proses pembelajaran bimbingan dan konseling harus dilakukan secara dinamis mengikuti perkembangan teknologi informasi dan perkembangan anak di era teknologi yang semakin canggih. Penelitian ini memiliki tujuan untuk mengetahui tingkat perbedaan minat belajar bimbingan dan konseling ditinjau dari metode pembelajaran Student Team Achievement Division pada siswa SMP Negeri 2 Kota Madiun. Lokasi penelitian adalah SMP Negeri 2 Kota Madiun Tahun Pelajaran 2016/2017 semester I kelas VII $G$ dan $H$ dengan jumlah masing-masing kelas sebanyak 26 siswa. Desain penelitian adalah eksperimen kuasi nonequivalent control group design. Teknik analisis yang digunakan adalah uji beda dengan pendekatan uji independent sample t test. Hasil penelitian menunjukkan bahwa nilai $t$ test minat belajar dengan diasumsikan kedua varians tidak sama adalah -2,355 dengan probabilitas 0,023; maka dapat disimpulkan bahwa ada perbedaan yang signifikan antara rata-rata minat belajar antara kelas yang diberikan treatment pembelajaran STAD dengan kelas yang tidak diberi pembelajaran STAD.
\end{abstract}

Kata kunci: Student Team Achievement Division, Minat Belajar, Bimbingan dan Konseling

\begin{abstract}
The process of counselling and guidance should be done dynamically, following the development of information technology and student development in the sophisticated era. The purpose of the research is to know the different level of student enthusiasm in counselling and guidance perceiving from Student Team Acheivment Division method in SMP Negeri 2 Madiun. The location of research is in SMP Negeri 2 Madiun in academic year 2016/2017, at first semester in class VII G and H each classconsists of 26 student. The research design is quasi experiment non-equivalent control group design. The analytical technique wich used is different test with the approach of independent sample $t$ - test. The result of the resarch shows that the $t$-test score of student enthusiasm wich is assumed as different variants is $-2,355$ by 0,023 in probability; so it can be concluded that there are significant differance between the average of enthusiasm for the classs wich is given the treatment by STDA methot and the class wich isn't given the method.
\end{abstract}

Keyword: Student Team Achievement Division, student enthusiasm, counselling and guidance 


\section{PENDAHULUAN}

Inovasi dan kreativitas dalam pembelajaran harus selalu dikembangkan seiring dengan perkembangan teknologi dan tantangan dunia pendidikan. Salah satu bentuk tantangan dalam dunia pendidikan khususnya dalam proses belajar mengajar adalah sikap dan perilaku siswa yang cepat berubah menuju hal yang positif maupun negatif. Perubahan sikap dan perilaku siswa lebih banyak dipengaruh oleh lingkungan siswa di dalam maupun di luar sekolah. Bentuk sikap dan perilaku positif yang mendukung proses belajar mengajar di sekolah adalah tingginya motivasi belajar siswa yang disebabkan adanya kemudahan penggunaan teknologi informasi sebagai sarana belajar mengajar. Untuk sikap dan perilaku negatif yang menghambat proses belajar mengajar adalah siswa merasa nyaman dengan keberadaan dunia maya dan jejaring sosial dalam bentuk facebook, whatshapp, instagram, twitter, game online dan lainnya, sehingga siswa menjadi malas untuk membaca buku dan mengerjakan tugas sekolah.

Adanya fenomena tersebut, maka guru juga harus mengikuti perkembangan siswa dan perubahan sikap serta perilaku siswa yang dapat menghambat proses belajar mengajar. Guru dituntut untuk lebih inovatif dan kreatif dalam proses belajar mengajar, hal ini disebabkan karena setiap siswa atau kelas memiliki ciri khas yang berbedabeda sehingga metode pembelajaran tiap siswa atau kelas juga seharusnya berbeda pula. Untuk menjawab tantangan ini, maka penulis melakukan treatment pembelajaran yang berbeda dari biasanya. Treatment pembelajaran ini didasari bahwa penulis menemukan adanya indikasi pada diri siswa yang memiliki motivasi rendah dalam belajar. Motivasi belajar yang rendah ditunjukkan dari sikap siswa yang sering mengabaikan tugas pokok belajar, karena siswa menganggap proses belajar mengajar tidak menarik dan tidak membangkitkan rasa ingin tahu siswa.

Bentuk metode yang digunakan dalam membangkitkan minat belajar Bimbingan dan Konseling adalah metode Student Team Achievement Division (STAD). Metode Student Team Achievement Division (STAD) adalah metode bentuk pembelajaran yang dikembangkan oleh Slavin sejak tahun 1995. Pembejaran ini secara garis besarnya memiliki langkahlangkah sebagai berikut: 1. Siswa dibentuk kelompok yang beranggotakan 4 siswa atau lebih dan kelompok tersebut bersifat heterogen; 2. Guru menyajikan pelajaran sesuai dengan topik bahasan yang telah ditetapkan sebelumnya; 3. Guru memberi tugas kepada kelompok untuk dikerjakan secara bersama-sama dengan anggota kelompok. Kelompok yang lebih paham dapat memberikan informasi kepada kelompok lain yang belum memahami materi; 4. Langkah selanjutnya adalah guru memberi pertanyaan kepada seluruh siswa, dan siswa lain yang tidak ditunjuk tidak boleh membantu dalam memberikan jawaban atau argumentasi; 5. Guru melakukan evaluasi berdasar materi dengan disesuaikan kemampuan siswa; 6 . 
Langkah terakhir adalah penutup dengan memberikan kesimpulan dari materi yang telah dibahas.

Penelitian ini juga mengacu pada hasil kajian empiris dari penelitian Antonius (2017), yang menemukan bahwa model pembelajaran STAD dapat meningkatkan hasil belajar siswa, khususnya mata pelajaran Matematika. Penelitian Elfina (2015), ada pengaruh positif antara metode pembelajaran kooperatif tipe STAD terhadap prestasi dan motivasi belajar siswa, khususnya pada mata pelajaran PKN. Penelitian Indrawati (2015), menemukan bahwa model pembelajaran kooperatif tipe STAD dapat meningkatkan hasil belajar siswa. Penelitian Nanik (2019), pembelajaran kooperatif model STAD dapat memotivasi peserta didik untuk meraih kemajuan dalam belajar. Penelitian Zainal dan Taufik (2014), menunjukkan bahwa ada kenaikan yang signifikan terhadap hasil belajar setelah diterapkan model STAD.

Tujuan penelitian ini adalah untuk mengetahui tingkat perbedaan minat belajar bimbingan dan konseling ditinjau dari metode pembelajaran Student Team Achievement Division pada siswa SMP Negeri 2 Kota Madiun.

\section{METODE PENELITIAN}

Penelitian dilaksanakan di kelas VII G dan VII H SMP Negeri 2 Kota Madiun Tahun Pelajaran 2016/2017 semester I, dengan jumlah siswa masing-masing kelas sebanyak 26 siswa. Penelitian ini memiliki kerangka berpikir, yang digambarkan sebagai berikut:

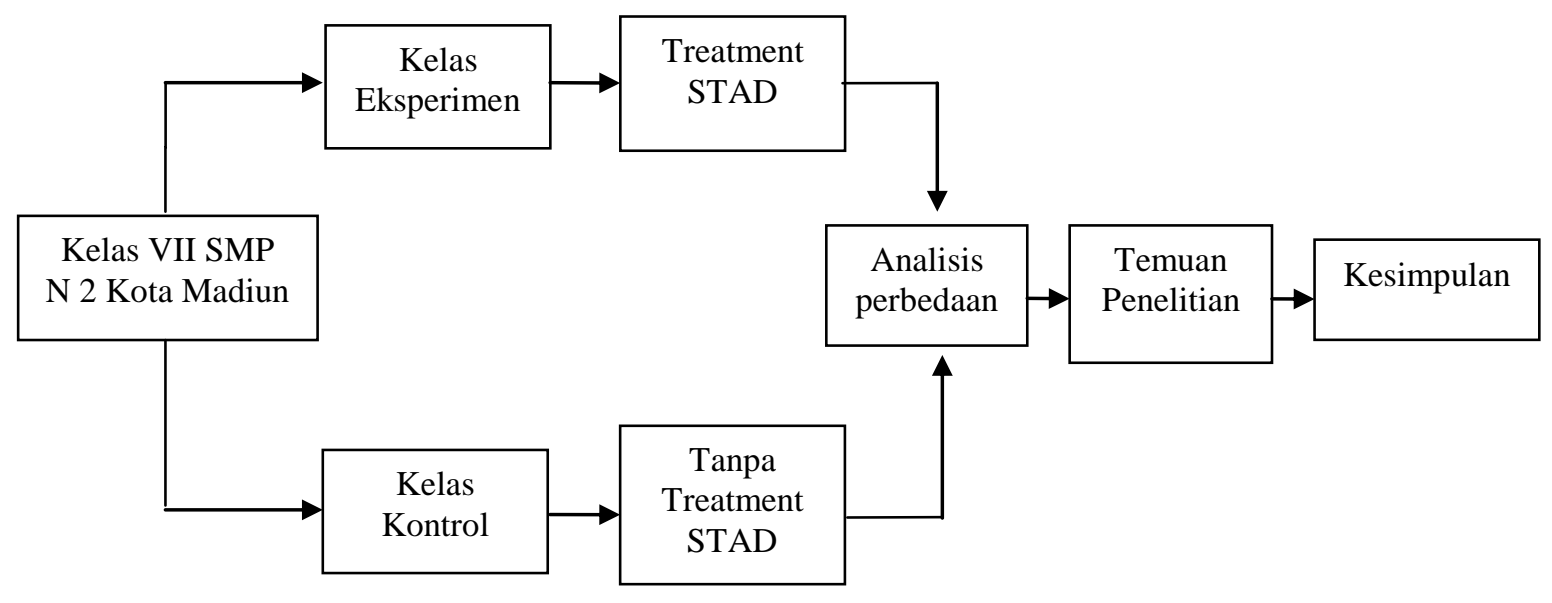

Gambar 1. Kerangka Penelitian

\begin{abstract}
Berdasarkan Gambar 1, maka dapat dijelaskan bahwa penelitian ini memiliki desain eksperimen kuasi nonequivalent control group design yang menggunakan dua kelas atau kelompok yang terdiri dari:
\end{abstract}

1. Kelas eksperimen, yaitu kelas yang diberi treatment pembelajaran STAD.

2. Kelas kontrol, yaitu kelas yang tidak diberi treatment pembelajaran STAD.

Kelas eksperimen diberikan treatment sebanyak tiga kali 
pertemuan. Pemilihan sampel untuk kelas eksperimen menggunakan metode nonrandom sampling, di mana penulis memilih kelas eksperimen dan kontrol berdasarkan pertimbangan guru kelas.

Data penelitian ini menggunakan angket pertanyaan yang berkaitan dengan minat belajar. Angket ini terdiri dari 15 item pernyataan minat belajar siswa.

Untuk mengetahui hasil penelitian ini, maka teknik analisis data yang digunakan adalah uji beda $t$ test. Uji beda t test dihitung dengan cara membandingkan nilai beda antara dua nilai mean dengan standar error dari data dua sampel. Uji beda $\mathrm{t}$ test memiliki tujuan untuk membandingkan mean dua kelompok yang tidak memiliki hubung satu dengan yang lain.

\section{HASIL DAN PEMBAHASAN}

Untuk mengetahui hasil penelitian ini, maka dilakukan uji Independent Sample T test dari data minat belajar antara kelas kontrol dan kelas eksperimen. Dari hasil perhitungan skor minat belajar siswa dapat dijelaskan sebagai berikut:

Tabel 1 Perbandingan Nilai RataRata Minat Belajar Siswa

\begin{tabular}{llcc}
\hline & Kelas & $\mathrm{N}$ & Mean \\
\hline $\begin{array}{l}\text { Minat } \\
\text { belajar }\end{array}$ & Kelas & 26 & 56.15 \\
siswa & Kelas & & \\
& $\begin{array}{l}\text { Eksperimen } \\
\text { Ekrol }\end{array}$ & & \\
\hline
\end{tabular}

Mengacu pada Tabel 1 diketahui bahwa nilai rata-rata dari kedua sampel, untuk kelas kontrol mempunyai rata-rata minat belajar sebesar 56.15 lebih rendah dibandingkan minat belajar dari kelas eksperimen yaitu sebesar 63.08. Hasil nilai rata-rata ini menunjukkan bahwa minat belajar siswa kelas eksperimen yang diberikan perlakuan pembelajaran STAD lebih tinggi daripada kelas kontrol yang tidak diberikan perlakuan pembelajaran STAD.

Langkah analisis selanjutnya adalah untuk melihat apakah perbedaan minat belajar kelas kontrol dan kelas eksperimen memiliki perbedaan yang signifikan atau tidak. Hasil pengujian dapat diketahui dari hasil output Independent Samples $t$ Test, sebagai berikut:

Tabel 2 Hasil Uji Independent Samples Test

\begin{tabular}{lrr}
\hline & \multicolumn{2}{c}{ Hasil Belajar } \\
\cline { 2 - 3 } & $\begin{array}{c}\text { Equal } \\
\text { variances } \\
\text { assumed }\end{array}$ & $\begin{array}{c}\text { Equal } \\
\text { variance } \\
\text { s not } \\
\text { assumed }\end{array}$ \\
\hline Nilai F & 1.223 & \\
Signifikansi & 0.275 & \\
Uji t & -2.355 & -2.355 \\
df & 50 & 41.675 \\
Tingkat & .023 & .023 \\
Signifikansi & & \\
\hline
\end{tabular}

Dari Tabel 2 diketahui bahwa nilai $\mathrm{F}$ sebesar 1,223 memiliki nilai signifikansi sebesar 0,275 ; artinya bahwa kedua varians cenderung berbeda sehingga uji yang digunakan adalah equal variance non assumed. Untuk nilai $\mathrm{t}$ test minat belajar dengan diasumsikan kedua varians tidak sama adalah $-2,355$ dengan probabilitas 0,023 . Oleh karena probabilitas < 0,05; maka dapat disimpulkan bahwa rata-rata minat belajar berbeda antara kelas 
yang diberikan treatment pembelajaran STAD dengan kelas yang tidak diberi pembelajaran STAD.

Dari hasil analisis independent samples $t$ test dapat disimpulkan bahwa ada perbedaan nilai rata-rata minat belajar siswa antara kelas eksperimen yang diberikan perlakuan pembelajaran STAD dengan kelas kontrol yang tidak diberikan perlakuan pembelajaran STAD.

Hasil analisis statistik ini juga didukung dengan hasil observasi di kelas saat dilakukan proses pembelajaran. Di mana keberhasilan pembelajaran STAD ditunjukkan dari kegiatan belajar mengajar yang berlangsung dengan baik dan kondusif. Ditinjau dari peran guru, maka guru mampu mendominasi kelas sebagai fasilitator dalam proses pembejaran, sehingga siswa lebih aktif dan termotivasi untuk mengemukakan ide dan gagasannya. Ditinjau dari siswa, maka siswa yang memiliki kompetensi dan pengetahuan yang lebih tinggi mampu memberikan pelayanan akademik kepada siswa lain yang belum paham terhadap materi. Ditinjau dari pengelolaan kelas, maka suasana kelas lebih hidup dan pelaksanaan diskusi menjadi cara yang baik untuk menggali informasi dari siswa. Selain itu, interaksi yang awalnya hanya berjalan satu arah (dari guru ke siswa) berubah menjadi dua arah (guru ke siswa dan siswa ke guru).

Hasil penelitian ini mendukung penelitian dari Antonius (2017), Elfina (2015), Indrawati (2015), Nanik (2019), Zainal dan Taufik (2014), yang menyatakan bahwa pembelajaran dengan model STAD mampu meningkatkan hasil belajar siswa.

\section{Pembelajaran dengan Model}

STAD dapat diimplementasikan dalam mata pelajaran bimbingan dan konseling pada tingkat SMP dan sederajat. Keberhasilan pembelajaran dengan model STAD ditandai dengan tingginya minat belajar siswa dibandinkan dengan kelas kontrol yang tidak menerapkan model STAD.

\section{SIMPULAN}

Berdasarkan hasil analisis kuantitatif dan kualitatif, maka dapat disimpulkan bahwa metode Student Team Achievement Division (STAD) dapat membangkitkan minat belajar siswa terhadap pelajaran bimbingan dan konseling, hal ini terlihat dari proses belajar mengajar yang berlangsung baik di dalam kelas. Selain itu, tanggapan siswa lebih positif dan ini tercermin dari hasil evaluasi yang dilaksanakan di kelas yang menunjukkan bahwa kelas dengan pembejaran STAD memiliki minat belajar yang lebih baik. Dari hasil analisis independent t test dapat disimpulkan bahwa ada perbedaan nilai rata-rata minat belajar antara kelas eksperimen yang diberikan perlakuan pembelajaran STAD dengan kelas kontrol yang tidak diberikan perlakuan pembelajaran STAD.

\section{DAFTAR PUSTAKA}

Antonius Widi Asmoro. (2017). Peningkatan Aktivitas dan Hasil Belajar Menggunakan Model Pembelajaran STAD pada Materi Barisan dan Deret 
Bilangan. Jurnal Edumath.

Volume 3 No. 1. Hlm. 28-33.

Elfina. (2015). Metode Pembelajaran

Kooperatif Model STAD

(Student Teams Achievement

Division) untuk Meningkatkan

Prestasi Belajar PKN Pada

Siswa Kelas VI SD Negeri 05

Nanggalo Kecamatan Koto XI

Tarusan Tahun Pelajaran

2013/2014. Jurnal Konseling dan Pendidikan. Vol. 3 No. 3, November 2015. hlm. 21-32.

Indrawati Sumuri. (2015). Penerapan Model Pembelajaran

Kooperatif Tipe STAD Untuk Meningkatkan Hasil Belajar Siswa Pada Materi Energi Panas di Kelas IV SD Inpres Siuna. Jurnal Kreatif Tadulako Online. Vol. 4 No. 12. Hlm.101-107.

Nanik Pudjowati. (2009). Implementasi Model STAD (Student Teams Achievement Divisions) Sebagai Upaya Peningkatan Apresiasi HAM pada Peserta Didik Kelas VII SMP 1. Jurnal Lemlit, Volume 3 Nomer 2, Hlm. 83-94.

Riyanto, Slamet. (2017). Statistik dengan Program IBM SPSS 24: Statistik untuk Pemula dan Contoh Riset Penelitian. Yogyakarta: LeutikaPrio

Zainal Aditama dan Taufiq Hidayat. (2014). Penerapan Model Pembelajaran Stad (Student Teams-Achievement Division) terhadap Hasil Belajar Ketepatan Service Bawah Bolavoli. Jurnal Pendidikan Olahraga dan Kesehatan. Volume 02 Nomor 01 Tahun 2014, Hlm. 41 - 44. 